\title{
Transatlantica
}

Revue d'études américaines. American Studies Journal

\section{Tennessee Williams's post-pastoral Southern gardens in text and on the movie screen}

\section{Taïna Tuhkunen}

\section{(2) OpenEdition}

1 Journals

\section{Édition électronique}

URL : http://journals.openedition.org/transatlantica/5406

DOI : $10.4000 /$ transatlantica.5406

ISSN : 1765-2766

Éditeur

AFEA

\section{Référence électronique}

Taïna Tuhkunen, «Tennessee Williams's post-pastoral Southern gardens in text and on the movie screen », Transatlantica [En ligne], 1 | 2011, mis en ligne le 03 janvier 2012, consulté le 29 avril 2021. URL : http://journals.openedition.org/transatlantica/5406 ; DOI : https://doi.org/10.4000/ transatlantica.5406

\section{Ce document a été généré automatiquement le 29 avril 2021}

\section{c) $(1)$}

Transatlantica - Revue d'études américaines est mis à disposition selon les termes de la licence Creative Commons Attribution - Pas d'Utilisation Commerciale - Pas de Modification 4.0 International. 


\title{
Tennessee Williams's post-pastoral Southern gardens in text and on the movie screen
}

\author{
Taïna Tuhkunen
}

The human machine is not no different from the animal machine or the fish machine or the bird machine or the reptile machine or the insect machine! It's just a whole God damn lot more complicated and consequently more trouble to keep together. Tennessee Williams, Cat on a Hot Tin Roof

1 In The Machine in the Garden, cultural historian Leo Marx summons up Nathaniel Hawthorne's 1844 depiction of a sudden, noisy intrusion of a train into the natural scene which disturbed the tranquility of the peaceful spot in the woods where Hawthorne had been meditating:

\begin{abstract}
But, hark! There is the whistle of the locomotive-the long shriek, harsh, above all other harshness, for the space of a mile cannot mollify it into harmony. It tells a story of busy men, citizens, from the hot street, who have come to spend a day in a country village, men of business; in short of all unquietness; and no wonder that it gives such a startling shriek, since it brings the noisy world into the midst of our slumberous peace. (Marx, 1964, 13)
\end{abstract}

2 Leo Marx identifies this acoustic incident caused by a train from the city as a major conflict within the American culture-the pastoral ideal on the one hand, industrialization and modern technology on the other-a clash, he claims, which has been resonating through American literature since the July day Hawthorne's reverie was broken up by the startling entry of a machine into the American Arcadia. Viewing the harsh whistle of the locomotive as something far more than a sound effect, Marx moves on to observe the collapse of the rural design in the works of other major American writers. In a more Southern context, the encounter between the agrarian ideal and the machine culture takes place, he argues, when a monstrous Mississippi 
steamboat suddenly emerges from the night in Mark Twain's Huckleberry Finn and smashes into the raft on which Huck and Jim had been peacefully drifting during their search for freedom, breaking the raft apart. After the examination of a few major works by American authors-including Emerson, Thoreau, Melville, Hawthorne, Twain and Fitzgerald-Marx concludes that while raising significant contradictions within American culture, "American writers seldom, if ever, have designed satisfactory resolutions for their pastoral fables" (364). In the end, "the American hero is either dead or totally alienated from society, alone and powerless, like the evicted shepherd in Virgil's eclogue" (364).

3 In my article, I wish to argue that the tension between the "pastoral" and the "progressive" pinpointed by Leo Marx persists in the form of a creative quarrel through several plays by the acclaimed Southern playwright and poet, Tennessee Williams (1911-1983) whose centennial was commemorated across the nation in 2011. Williams's works are not explicitly mentioned in The Machine in the Garden, but they challenge the underlying pastoral conception of the "American garden" without solving the cultural complexities posed by that very myth. While the wood cabin in Emerson's Walden; or life in the woods and the southward-floating raft in Twain's Huckleberry Finn offer "the chance of a temporary return to first things" (69) as Marx writes, Williams's post-Edenic gardens offer no similar settings for temporary returns to rural happiness. Instead, we are left to make sense out of broken decors and fragmented icons imbued with nostalgia, as well as of the jarring sounds echoing through what Matthew Roudané calls Williams's "poetic stage moments, moments in which social fact, psychological collapse, and eroticized encounter form a still point in which the imagination, itself, becomes the last refuge for his fated characters" (Roudané, 1997, 1).

Bearing in mind Roudanés perception of imagination as the ultimate shelter or sanctuary, I shall focus briefly on five film adaptations based on the works of the Mississippi-born playwright-A Streetcar Named Desire (Elia Kazan, 1951), Baby Doll (Elia Kazan, 1956), Cat on a Hot Tin Roof (Richard Brooks, 1958), Suddenly Last Summer (Joseph L. Mankiewicz, 1959) and The Night of the Iguana (John Huston, 1964)-to see how the garden imagery and the romanticized old South "plantation paraphernalia" (Bargainnier, 2006, 245)are reworked into more contemporary cinematographic Souths. For, unlike most mainstream heritage films that tend to represent the American South as an uncorrupted space of equilibrium and easy living, the mid- $\mathrm{xx}^{\text {th }}$ century film scenarios based on Williams's works distance themselves from the former, idealized cinematographic Souths, digging through the fine facades into the psychic dissonances of a world struggling with its past.

Strikingly enough, the Williamsian garden is permeated, right from the start, with loss and degeneration, also in the acoustic sense of the two words. As illustrated by $A$ Streetcar Named Desire, adapted to the cinema by Elia Kazan, sounds make sense in a number of ways in these fictitious $\mathrm{xx}^{\text {th }}$ century screen Souths, and even if the "machine in the garden" undoubtedly turns into something more mental or metaphorical than purely technological, both in text and on screen, the startling "shriek" motif is still audible. Not necessarily machine-made, as Elia Kazan's soundtracks suggest, it remains intimately connected with the anxiety and alienation of the machine-age, submerging the more pleasurable sounds and musical effects with hostile echoes. 
6 In A Streetcar Named Desire, the lost plantation "Belle Reve" is first presented in the form of a fading snapshot before the Southern lady is, in the blunt words of a car mechanic named Stanley Kowalsky (Marlon Brando), "pulled [...] down off them columns" (Williams, 1987, 199). The colored city lights of New Orleans-evocative of the new, urban South-are turned on as the vanishing Old South recedes in front of a gaudier, noisier industrial world. To the dismay of Blanche DuBois (Vivien Leigh), dressed in a dainty garden party outfit in a world pierced by cacophonous jungle cries, her brotherin-law acts like an ape and screeches like a cat, whilst her younger sister Stella (Kim Hunter) turns into a carnal woman ready to "hang back with the brutes" (164). Stellathe-Star's final fall from the pedestal is dramatized during a memorable saxophonebacked staircase sequence as Alex North's radically new type of dissonant jazz score backs up Kazan's camera work, spectacularizing Hunter's slow, sensuous descent into Brando's rough and sweaty arms. Similarly to the play text, the diegetic space of the movie echoes with street noises and coarse howls, and with the clamor created by the "psychic train" Blanche is the only protagonist to perceive. Like the anachronistic gun shots that do not belong to the diegetic space of the movie, the locomotive "shrieks" connect the raw post-Arcadian times with the past which, to paraphrase William Faulkner's oft-quoted words, is never totally dead nor perfectly past.

7 The always already tainted and contaminated Southern garden imagined by Williams is saturated with synaesthesia, a "disorder" particularly well-suited for the cinema. Creating effects where sights, sounds and smells intermingle, the playwright provided movie makers with a rich reservoir of stage directions, an endless webwork of intersections between Southern History, stories, symbols, myths and typologies. Although Williams is far from being the only American author exploiting the rich matrix of Southern traditions and legends, its plantation culture and epic grandeur marked by more or less dutiful Belles, chivalrous gentleman callers and coded manners, his impact has been crucial in bringing the larger-than-life epic South into contact with the more unruly, intimate aesthetics of modern times attached to fusion and movement -most noticeably, by revealing the primitivism and luridness beneath the genteel surface, forcing the South to confront some of its untold stories of decadence, madness, incest and human sacrifice. Yet, while the racial Other seldom surfaces in the screen adaptations of Williams's works otherwise than via fleeting metaphors or figures, his postbellum South is, markedly enough, a place of decadent whiteness where the enactment of psychological crises still often requires a garden-like environment. Whether a dilapidated plantation house (Baby Doll), an old estate bought by the industrious son of a hobo (Cat on a Hot Tin Roof), an indoor garden of a bourgeois town house (Suddenly Last Summer), or an exotic natural garden on a hilltop in Mexico (The Night of the Iguana), Williamsian Souths take us beyond the overdetermined spaces of the canonical southern cinema of the 1930s and 1940s, by creating disorder in the iconic landscapes and by letting the hideous wilderness seep in and merge with the Arcadian garden.

\section{The reptile beneath the porch in The Night of the Iguana}

8 In the filmic Southlands based on the works of Tennessee Williams, the present-day world is repeatedly set up against the backdrop of a bygone world of noble fathers, untarnished daughters and seemingly perfect gardens: all well-known features of the 
American South popularized by the cinema. Yet, what Williams prefers us to see is the creature at the end of its rope, pulling away from the prearranged decor.

This is dramatized most visibly in The Night of the Iguana, a 1964 movie by John Huston where the main protagonist is a defrocked church father, Reverend Shannon (Richard Burton) who, after losing his faith and his pulpit, has ended up as a distressed south-ofthe-border tour guide to Mexico. Huston dramatizes the battle between the godly and the lowly through his film by alternating perspectives, moving from the nasty-looking reptile to a jungle hilltop or to a stormy sky and back again to the earth-bound protagonists. After the opening credits which provide a prolonged close-up on an iguana, the camera pans down from the top of a church steeple to a notice board stuck to the ground posting the topic of the day's sermon ("Spirit of truth"), before cutting to the next scene inside the church where Reverend Shannon's vociferous yet short-lived mass is about to begin.

10 The subsequent sequence, an addition to Williams's text, constitutes a cinematographic statement of its own as Shannon is seen through a low-angle shot high in his pulpit as a figure of authority. Soon, however, the hymn-singing parishioners grow uneasy and start leaving the temple before the sermon is halfway through. The words lashed out at the churchgoers by the Reverend collide with the pastoral iconography as the good shepherd-the leading figure of the classic, Virgilian mode also evoked in TheMachine in the Garden-turns into an irate preacher who pursues his flock to the church door with his hollering. It is only after this unexpected prologue that Huston embarks his spectators on a bus journey with an all-female mini-congregation during which the clergyman undergoes a second fall from grace, succumbing to the charms of Charlotte Goodball (Sue Lyon), a 17-year-old sex-hungry kitten, another female predator prowling around the priest, and as Lesley Brill notes in John Huston's filmmaking, “Iguana often looks like an amplification of the Sartrean idea of hell as other people whom one can neither escape nor make authentic contact with." (Brill, 1997, 96).

11 Later on, Huston focuses on the eponymous lizard tied up to a pole, pitting the mute beast against the profuse vocalizations of female creatures whose voices constantly disturb the equilibrium of the natural setting in this other film on Hustonian "misfits," a heterogeneous group composed of Maxine Faulk, the owner of a seedy hotel (Ava Gardner), Hannah Jelkes, a sketch artist (Deborah Kerr) and her moribund poet grandfather (Cyril Delevanti), as well as a busload of pathetic, pious women pursuing Reverend Shannon. For most of the film, the wild animal waiting to be slaughtered for meat is chained to the porch of the jungle-top hotel called "Costa Verde" ("green coast"), so unlike Hawthorne's "happy valley." And like the tethered animal, the runaway priest keeps tossing and turning in his own straitjacketed existence. Tied to a hammock by Maxine and Hannah, the two women each of whom represents a facet of Shannon's dual stance towards sexuality and religion, flesh and spirit, the animal mirrors Shannon's predicament. The women save the reverend from suicide and the iguana is finally released, but whether the Mexican hilltop, presented as the Garden of Gethsemane for the perpetrator as well as the victim of the holy word ultimately turns into a new Eden or a Golgotha remains a thorny issue.

Williams's animal allegories would hardly be as gripping were they not such convoluted fusions of the savage and the sensual, making it difficult to tell gentility apart from barbarity. The excursion to Mexico in The Night of the Iguana is no exception, although unlike other major plays by Williams, it is not set in Louisiana or in Mississippi, but 
beyond the geographical borders of the American South. Yet, whatever their exact location on the map, Williamsian characters remain entangled in history, both personal and biblical, hauling their private hells along wherever they go. And whilst marked by a definite decline of powerful Daddies, self-sacrificing Big Mamas, sons powerless to pursue their fathers' legacies and younger women submitted to honor codes, the Williamsian South is also a place of punitive gods, straitjackets, lobotomies and other coercive methods used by society to maintain control. After the emblematic lizard is released and vanishes beneath the shrubs of the Mexican jungle, the ultimate catharsis is doubtful. As Peggy W. Prenshaw claims in her article "The Paradoxical Southern World of Tennessee Williams", even if Williams is committed to the Romantic view according to which the natural equals the good, his writings are often "far too permeated with a sense of sin, to be able to accept such an idea with equanimity." (Prenshaw, 1980, 8).

\section{Big Daddy and other enchanting Southern beasts}

Verticality is given further emphasis in other filmic rereadings of Tennessee Williams's plays. High and low angle shots continue to reveal the Southerners' obsession with ascension and descent, namely by means of an ornate elevator in Suddenly Last Summer or a staircase in Cat on a Hot Tin Roof, a complex signifier and a dramatic site of confrontation already in the 1930s' Southern blockbusters Gone with the Wind (Victor Fleming, 1939) and Jezebel (William Wyler, 1938). The magnificent, central staircase of Twelve Oaks is demolished in Selznick's superproduction, yet its implicit presence keeps haunting cinema screens in a number of later restagings of the American South still marked by fantasies about stairways to heaven.

In Framing the South: Hollywood, Television and Race during the Civil Rights Struggle, Allison Graham writes about Hollywood representations of the South after the 1930s and 1940s:

By the mid-1950s, white Americans' love affair with the plantation myth had undergone several revisions, but the infatuation was as strong as ever. Under the spell of Tennessee Williams, Hollywood modernized its antebellum sets and filmgoers were treated to a new spectacle of southern decay. The mansions, juleps, and magnolias remained, but the residents of the screen South now began to enact the psychological crises of a dwindling subculture (Graham, 2001, 20).

While the "new spectacle of southern decay" coincided with a move towards novel predicaments, the degenerated cinematic South was still a world of uplifting, upsetting women-Belles who threw away their XIX ${ }^{\text {th }}$ century Victorian masks of gentility. At the same time, as R. Barton Palmer has pointed out, Williams helped popularize "a different kind of masculinity, offering images of desirable, vulnerable, and yet aggressive maleness that profoundly affected American ideas about gender" (Palmer, 1997, 231). This is certainly the case in Cat on a Hot Tin Roof, another of Williams's prize-winning plays adapted to the cinema. Richard Brooks's 1958 film version of the play centers on the baroque pathology of a Southern family gathered around a cancer-stricken "Big Daddy" (Burl Yves) and his alcoholic, broken-ankled son Brick (Paul Newman), before it re-establishes the power of the fathers at the head of the family. It is Brick Pollitt's wife, Maggie (Elizabeth Taylor), the unorthodox Southern Belle and the real "cat" of the story who stands out as the most genuine and truthful character of the tale, and even when Maggie lies about her pregnancy, her animal energy fights off the guilty 
secrets and the "obnoxious odor of mendacity" which have overtaken the Mississippi Delta's biggest estate, turning it into a mouse-trap of sorts.

In Cat on a Hot Tin Roof, the plantation culture, well past its peak, has abandoned its patrician ideals and courtly traditions. No longer occupied by the sons of agrarian forefathers, the big white house emulating ancient Greek dwellings was acquired after years of hard work by a rootless former overseer. Pervaded with the air of ostentatious wealth, malaise and betrayal, the new rural South is best emblematized by Big Daddy Pollitt, the cancerous patriarch and his grandchildren, bred by the elder son Gooper (Jack Carson) and Mae, his ex-Cotton Carnival queen and "fertility monster" spouse (Madeleine Sherwood) who is doing her utmost to ensure that her offspring, the "noneck monsters" will inherit the mighty Mississippi plantation. Noisy carnivalesque scenes punctuate the film giving it a circus-like rhythm as a result of the grandchildren's ear-splitting performances of Dixie fanfares meant to entertain the dying patriarch, while adult voices ring through the mansion and its garden "hollering about the truth" as Maggie remarks about the uncivil war raging between the Williamsian loners. Viewed through Maggie's eyes, Mae's performance of family bliss and (hetero/)normativity looks more like a Mardi Gras parade, and there is little doubt that it is "Maggie the Cat"-one of the most memorable good bad women and enchanting beasts of the American South-who is the persona through whose voice Williams best derides the voracity and the smug provincialism of the new generation of Southerners installed in the old plantation decor.

On the whole, there is something quite Citizen Kanish about Brooks's way to film Williams's rags-to-riches story where farming and gardening have ceased to represent the ideal human activity in the Jeffersonian sense of the expression. The farm is now big business in the hands of new Southern daddies, and although the "machine in the garden" is not pictured in Cat on a Hot Tin Roof otherwise than by means of airplanes, convertible cars and bulky station wagons used by the new plantation owners, we understand that the previously rustic South has succumbed to industrialized thinking and become a "factory in the field" prone to mass production. Like the megalomaniac newspaper publisher in his pharaonic Xanadu palace in Orson Wells's 1941 Citizen Kane, the "Mississippi emperor" hangs on to his godlike kingdom and his own "rosebud" -an empty suitcase that belonged to his traveling worker father who died by the railroad with a smile on his face. It takes, however, the discovery of father Pollitt's inoperable disease to expose the absurdity of his strive for immortality. The costly statues, mirrors, paintings and other art objects hauled from Europe, piled-up in meaningless heaps in the cellar, offer the perfect setting for the therapeutic confrontation between the dying patriarch and his son, Brick, who finally have the guts to sort their ways through the father's accumulated possessions and the son's self-loathing, down to the difficult four-letter word "love." And, as if to encapsulate the complex moral and sexual dilemmas of the play, Brooks resorts to another Williamsian animal metaphor to put an end to the father-son verbal duel, creating a cathartic instant where the distinction between man and beast is nearly obliterated: "The human animal is a beast that eventually has to die of a crazy hope that one of the things he buys will be life everlasting which it never can be."

Brooks's Cat on a Hot Tin Roof closes on a curiously Hollywoodian, un-Williamsian happy ending. Taylor's Maggie sheds off her cattiness when dashing, angel-like, in her white dress up the grand staircase answering her husband's call to join him in the upstairs 
bedroom-to conceive, it is understood, the awaited heir to the estate. Not only does the film restore Brick's masculinity, purging the plantation bedchamber of previous allusions to same-sex desire, but Maggie-Mary's announcement of her pregnancy reads as a sign of regeneration of the entire Southern family: "A child is coming, sired by Brick out of Maggie the Cat." Finally, contrary to the two alternate endings Williams wrote for the play, all three Pollitt men in the film agree that Maggie-unlike the childrearing yet oddly lifeless Mae, collapsed at the foot of the stairs-has "life in her body". As Brick puts it: "[T]ruth is something desperate and Maggie's got it. Believe me, it is desperate and she's got it!"

\section{The jungle-garden in Suddenly Last Summer} and a more fantastic Williamsian fable where the central locus is no longer a jungle, nor a Mississippi mansion, but a man-made spot of wilderness within a posh town house in the Garden district of New Orleans. Because of censorship restrictions, still severe in the late 1950s, both Cat on a Hot Tin Roof and Joseph L. Mankiewicz's Suddenly Last Summer avoided the taboo topic beneath both plays: homoeroticism and the adjacent Williamsian figure of the "dead queer." Despite the Production Code Administration's surveillance of the film adaptations of his texts, Williams's powerful animal and botanical allegories, as well as his rich realistic and expressionistic techniques seem, however, to have protected the adaptations against the worst watering down of the subplots.

In Suddenly Last Summer, a fine New Orleans residence is presented as an entranceway to what lies behind the respectable façade of the old house: a mysterious hinterland created by Sebastian Venable, a dead poet whose haughty, castrating mother, Mrs. Violet Venable (Katharine Hepburn), is committed to transforming his deceased son into a monument. In a characteristically Williamsian mix, Sebastian's garden blends sights and sounds, utter sophistication and utmost cruelty, and it is this primordial jungle recalling, in Mrs. Venable's words, the "dawn of creation"-reminiscent of other multisensory "shrubs with vivid trumpet-shaped flowers" (Williams, 2001, 228) in The Night of the Iguana-that leads to other emblematic places. Namely to the Galapagos Islands where Sebastian forced her mother to observe the ghastly spectacle of rapacious, shrieking birds feeding on newly hatched sea turtles. It is only at the end, under the effect of truth-serum that the post-Darwinian substory beneath the animal allegory is revealed and that we learn from Mrs. Venable's niece Catherine (Elizabeth Taylor) how Violet lured young men to satisfy the sexual appetite of her predatory son, before Sebastian died by cannibalism in the hands of those he had exploited sexually.

21 As in Cat on a Hot Tin Roof, Elizabeth Taylor is cast in the role of an impetuous, younger Southern woman as a counterforce to a tormented and fragile Adam in an already corrupt garden. It is through flashbacks that we realize Catherine Holly's tragic transformation into bait, a role of procurer of young men Sebastian used to confer to his mother-the "wicked lady" exuding a "marvelous perfume" of the same kind as the insectivorous plant, Venus flytrap in Sebastian's garden-before Violet grew too old for the peculiar assignment. Here the corruptive power of "mendacity" seems to be spreading into the field of medicine, as Mrs. Venable seeks to put an end to her niece's "obscenities" or "babbling" by means of lobotomy.

Transatlantica, 1 | 2011 

patients are deprived of their vitality, transformed from "wild animals" into robot-like creatures without desires or wills of their own-the play begins as Dr. Cukrowics (Montgomery Clift), a famous neurosurgeon, visits Mrs. Venable who is about to make an important donation to the state mental hospital in exchange for an operation to excise Catherine's recollections of what had happened suddenly, the previous summer. With its intersecting roots that form a dense webwork of biblical, botanical and medical references, Williams's "garden play" clearly outgrows the confines of the Christian world governed by a single tree of knowledge. And once again, it is the conflicting, mutually incompatible versions of the "truth" that tear the protagonists apart. When entering Sebastian's garden for the first time, one cannot but agree with the doctor called in to act as an arbiter who finds the Venable garden "well-groomed and, frankly a little terrifying." Indeed, what makes this patch of indoor wilderness so disquieting is not only the prehistoric trees and insectivorous plants, but the fact that somebody would be so keen on keeping it so well-tended. As Williams's stage directions emphasize, this is a grotesque garden, a place where human and animal forms intersect with those of plant life, blurring the limits between flora and fauna, between the human and the inhuman, distorting finally the very word "natural":

The interior is blended with a fantastic garden which is more like a tropical jungle, or forest, in the prehistoric age of giant fern-forests when living creatures had flippers turning to limbs and scales to skin. The colours of this jungle-garden are violent, especially since it is steaming with heat after rain. There are massive treeflowers that suggest organs of a body, torn out, still glistening with undried blood; there are harsh cries and sibilant hissings and trashing sounds in the garden as if it were inhabited by beasts, serpents and birds, all of savage nature... (Williams, 1968, 113)

As opposed to the formal, symmetrical gardens of the jardin à la française where every tree and shrub is ruled by an attempt to submit nature to the will of man, what prevails in the jungle-garden in Suddenly Last Summer is the aesthetics of disarray. Mankiewicz's filmic recreation of Williams's literary grotesqueries takes into account the playwright's voicing as well as visual strategies, and not only are the "harsh cries" and "sibilant hissings" replaced by Buxton Orr's suggestive musical score, but the dead poet's name is pronounced with such spine-chilling precision by his mother that it seems to freeze the hothouse atmosphere of the film. The presence of the dead poet whose life was spent fighting "against the herbaceous border" is evoked through backdrop elements (statues, vanitas) which the characters on the set seem to take no notice of, but which the spectators cannot fail to see, thus establishing a relationship of complicity between the absent master-mind of the garden and the reader-spectator of the movie.

24 At the end, the Venable garden, an allegorical place for Dionysian rituals, including dismemberment and cannibalism, leaves the spectator pondering over the exact nature of sacrifice in Suddenly Last Summer-a play John M. Clum sees as an expression of Williams's paganism, as yet "another blasphemous Eucharist" (Clum, 1997, 133). For Clum, Sebastian's garden and its carnivorous plants is the true expression of Williams's vision of the fallen world, while its operative principle remains hunger and desire. We might add, that like the European settlers who dreamt of a promised land of easy living in the American South, but discovered a semi-tropical garden of discomfort, Tennessee Williams's South often turns out to be a trap. Shaped as an ambivalent land of bountiful 
"meta-flora," his Southern gardens resonate with violence and desire and bear "strange fruit"-to employ the metaphor of Billie Holiday's famous song whose lyrics challenge the very sweetness and freshness of the "pastoral scene of the gallant South".

\section{Chases through a Southern dollhouse}

Before leaving Tennessee Williams's startling gardens, let us note that not all of them ooze with pernicious sensuality. Some of his ruined Edens become, on the contrary, perfect places for the carnivalesque and the tragicomic. Undeniably the best example of the conversion of the aristocratic Southern garden estate into a place of farce is Baby Doll, another of Williams's plays adapted to the big screen by Elia Kazan in a movie finger-pointed for its carnal suggestiveness by censorship authorities who gave the film a "C" ("condemned") rating at its release in 1956.

Baby Doll opens on a panoramic view on a sterile landscape surrounding an old house in rural Mississippi. The ante-bellum mansion-a decrepit dwelling, a common metonymy for the crumbling Southern culture-becomes the theater for a series of burlesque scenes as the olden and golden civilization is turned into ridicule. Even the retired black men who dawdle around the "doll house" and whose ancestors slaved for the previously prosperous place roll with laughter at the pathetic spectacle offered by the white master, Archie Lee Meighan (Karl Malden), scuttling around most of the film in a vain effort to keep up appearances. The tone is set by the opening sequence, as the spectator is invited to chuckle with the great-grand-sons of "happy darkies" transformed into "happily laughing darkies."

As Kazan's camera pans closer, the old house is brought to life by the bellowing master of the place-Archie, a cotton-gin owner, a distorted avatar of a Southern gentleman who later destroys the cotton gin of his archrival, Silva Vacarro (Eli Wallach) in a frantic effort to keep hold of his estate and of his young, whimsical wife (Carroll Baker). The comic irony of the script rises from the public secret beneath Archie's marriage. When marrying Baby Doll Meighan, Archie had promised her Daddy that he would wait until the bride's twentieth birthday for the marriage to be consummated. The film begins when the long-awaited day of deflowering has arrived, and Archie, set up as a ludicrous Peeping Tom, is digging a hole through the wall to peer into Baby Doll's bed chamber. Later on, the spectator is offered Chaplinesque cat-and-mouse scenes full of sexual allusions as Vacarro, the wolfish Italian, literally a "cowman," is chasing Archie's virgin wife up to the rotting attic while Archie, the baby-crazed "good old Southern boy" is out trying to avenge the Sicilian. Finally, as the increasingly frantic Archie resorts to guns, he is picked up by the police, and once again the Williamsian plot ends on a question mark as we are left pondering what will become of the characters. Whatever the case, Baby Doll is no longer the thumb-sucking child-woman sleeping in a crib where she was dozing when Archie's and the spectators' gaze surprised her.

In order to better appreciate the clashing sights and sounds of the South, it may be of interest to know Kazan's reply when asked about Baby Doll's ultimate significance:

Baby Doll is a black comedy. It has no meaning. It's chaos; it's a microcosm of the changing South as I know it and like it. [...] Archie Lee is the old, landed aristocracy. The new uneducated drive forward and the fulfillment of self is Baby Doll. And the catalyst between the two is Silva, the hot-shot industrialist whom Tennessee Williams caught in the form of a little cocky sparrow. It's the story of the South at that time played by small little insects (Young, 1999, 224). 
One could indeed claim that rather than forming a string of tableaux vivants, the cinematographic Souths shaped by filmmakers stimulated by Williams's texts often read as a series of tableaux grouillants, literally "swarming" with poetic detail and allegorical animal activity. Whether a busload of babbling women led by an edgy clergyman (The Night of the Iguana), a group of teeth-gnashing relatives behind the walls of a Southern mansion (Cat on a Hot Tin Roof), insectivorous plants amidst the foliage of a well-tended New Orleans garden (Suddenly Last Summer), or men and women shrieking through a ramshackle house somewhere down in Mississippi (Baby Doll), the cinematographic Souths inspired by Tennessee Williams's plays teem with life-despite the concurrent signs of loss, fall and decay.

\section{BIBLIOGRAPHIE}

CLUM, John M., "The sacrificial stud and the fugitive female in Suddenly Last Summer, Orpheus Descending, and Sweet Bird of Youth", in The Cambridge Companion to Tennessee Williams, Matthew C. Roudané, ed., Cambridge, Cambridge University Press, 1997.

BARGAINNIER, Earl F., "Moonlight-and-Magnolias Myth”, in Myth, Manners, \& Memory, The New Encyclopedia of Southern Culture, Vol. 4, Charles Reagan Wilson, ed., Chapel Hill, University of North Carolina Press, 2006.

BRILL, Lesley, John Huston's filmmaking, Cambridge, Cambridge University Press, 1997.

GRAHAM, Allison, Framing the South: Hollywood, Television and Race during the Civil Rights Struggle, Baltimore and London, The Johns Hopkins University Press, 2001.

MARX, Leo, The Machine in the Garden, New York, Oxford University Press, 2000 (1964).

PALMER, R. Barton, "Hollywood in crisis", in The Cambridge Companion to Tennessee Williams, Matthew C. Roudané, ed., Cambridge University Press, 1997.

PRENSHAW, Peggy W., "The Paradoxical Southern World of Tennessee Williams” in Tennessee Williams: 13 Essays, Jac Tharpe, ed., Jackson, Mississippi, University Press of Mississippi, 1980.

ROUDANE, Matthew C., dir., The Cambridge Companion to Tennessee Williams, Cambridge, Cambridge University Press, 1997.

WILLIAMS, Tennessee, A Streetcar Named Desire and Other Plays, London, Penguin Books, 1987 (1947).

WILLIAMS, Tennessee, "Suddenly Last Summer" (1958) in Baby Doll and Other Plays, London, Penguin Books, 1968.

WILLIAMS, Tennessee, "The Night of the Iguana" (1963) in Cat on a Hot Tin Roof and Other Plays, London, Penguin Modern Classics, 2001.

YOUNG, Jeff, Kazan: the Master Director Discusses His Films: Interviews with Elia Kazan, New York, Newmarket Press, 1999.

Transatlantica, 1 | 2011 


\section{RÉSUMÉS}

Cette étude se penche sur la représentation du Sud états-unien dans l'adaptation cinématographique de cinq pièces du dramaturge américain originaire du Mississippi, Tennessee Williams: Un tramway nommé désir (Elia Kazan, 1951), La poupée de chair (Elia Kazan, 1956), La chatte sur un toit brûlant (Richard Brooks, 1958), Soudain l'été dernier (Joseph L. Mankiewicz, 1959), et La nuit de l'iguane (John Huston, 1964). L'article met en évidence, chez Williams, la représentation irrévérencieuse du paradigmatique jardin sudiste qui, s'il conserve certains de ses attributs classiques et bibliques, ne s'avère pas moins dynamique. En s'appuyant sur la conception du jardin pastoral théorisé par Leo Marx dans The Machine in the Garden (1964), l'auteur s'attarde sur la façon dont le cinéma du milieu du $\mathrm{xx}^{\mathrm{e}}$ siècle cherchait à recréer le jardin williamsien comme un lieu corrompu et déshumanisé, traversé de cris inquiétants.

This study explores the representation of the American South in the film adaptations of five plays by the Mississippi-born playwright, Tennessee Williams: A Streetcar Named Desire (Elia Kazan, 1951), Baby Doll (Elia Kazan, 1956), Cat on a Hot Tin Roof (Richard Brooks, 1958), Suddenly Last Summer (Joseph L. Mankiewicz, 1959) and The Night of the Iguana (John Huston, 1964). The article focuses on the disrespectful representations of the paradigmatic Southern garden which remains dynamic while maintaining some of its classic or biblical features. By relying on the conception of the pastoral garden as theorized by Leo Marx in The Machine in the Garden (1964), the author pays specific attention to the way mid-xxth century cinema kept recreating Williams's Southern gardens as a corrupted and dehumanized space pierced through by disquieting shrieks.

\section{INDEX}

Keywords : Tennessee Williams, corrupted garden, Southern gardens, animal allegories, Southern Belles, cinema of the South, sights and sounds.

\section{AUTEUR}

\section{TAIINA TUHKUNEN}

Université de Versailles Saint-Quentin-en-Yvelines 